\title{
Diet and feeding daily rhythm of Pimelodella lateristriga (Osteichthyes, Siluriformes) in a coastal stream from Serra do Mar - RJ
}

\author{
Mazzoni, $R .^{\mathrm{a} *}$, Moraes, $M .^{\mathrm{a}}$, Rezende, $C F^{\mathrm{b}}{ }^{\mathrm{b}}$ and Iglesias-Rios, $\mathrm{.}^{\mathrm{c} *}$ \\ ${ }^{a}$ Departamento de Ecologia, Instituto de Biologia Roberto Alcantara Gomes, \\ Universidade do Estado do Rio de Janeiro - UERJ, Rua São Francisco Xavier, 524, \\ Maracanã, CEP 20550-013, Rio de Janeiro, RJ, Brazil

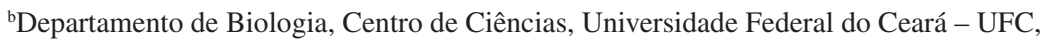 \\ Campus do Pici, CEP 60455-970, Fortaleza, CE, Brazil \\ ${ }^{\mathrm{c}}$ Departamento de Ecologia, Instituto de Biologia, Universidade Federal do Rio de Janeiro - UFRJ, \\ CP 68020, Rio de Janeiro, RJ, Brazil \\ *e-mail: mazzoni@uerj.br, rir@biologia.ufrj.br
}

Received November 10, 2009 - Accepted December 21, 2009 - Distributed November 30, 2010

(With 3 figures)

\begin{abstract}
The present study was carried out in Mato Grosso fluvial system, a costal drainage from Serra do Mar. We analysed the diet and the feeding daily rhythm of Pimelodella lateristriga from samples carried out during 24 hours over a 4 hour fishing interval, in June, July and September, 2006 as well as in January and February, 2007. Diet was described from the Feeding Index (IAi) and feeding daily rhythm was verified through the Gut Fullness Index (GFI). Pimelodella lateristriga diet was composed of 37 items, being aquatic insects the most important ones. IAi analysis revealed that Diptera, Trichoptera and Ephemeroptera amounted to $90 \%$ of the diet. Autochthonous invertebrates were the most important consumed items. Pimelodella lateristriga concentrated its feeding activities in the nocturnal period (10:00 PM to 2:00 AM) with marked significant differences $(\mathrm{F}=16.11 ; \mathrm{gl}=5 ; \mathrm{p}<0.05)$ between each diurnal and nocturnal periods. Between 6:00 AM and 6:00 PM, foraging activity was gradually reduced. We concluded that $P$. lateristriga has an insectivorous diet and a nocturnal feeding habit with greater activity between 10:00 PM to 2:00 AM.
\end{abstract}

Keywords: trophic ecology, feeding daily rhythm, stream-dwelling fishes.

\section{Dieta e ritmo diário da alimentação de Pimelodella lateristriga (Osteichthyes, Siluriformes) de um riacho costeiroda Serra do Mar - RJ}

\section{Resumo}

O presente estudo foi desenvolvido no sistema fluvial do rio Mato Grosso que compõe uma drenagem costeira da Serra do Mar. Foi analisado o hábito alimentar e o ritmo alimentar diário de Pimelodella lateristriga a partir de amostras obtidas em coletas de 24 horas, com intervalos de 4 horas, em junho-julho-setembro/2006 e janeiro- fevereiro/2007. A dieta foi avaliada a partir do Índice Alimentar (IAi) e o ritmo alimentar diário, com base no Índice de Repleção Estomacal (GFI) dos peixes. A dieta de P. lateristriga foi composta por 37 itens, sendo os insetos aquáticos os mais abundantes. O IAi revelou que Diptera, Trichoptera e Ephemeroptera somaram $90 \%$ da dieta, sendo, portanto, os invertebrados autóctones os itens mais consumidos. Pimelodella lateristriga concentrou sua atividade alimentar no período noturno (10:00 até 14:00 horas) com diferenças significativas $(\mathrm{F}=16,11 ; \mathrm{gl}=5 ; \mathrm{p}<0,05)$ entre os horários diurnos e noturnos. Entre os horários 6 am e 6 pm a atividade de forrageamento foi gradualmente reduzida. Concluímos que P. lateristriga possui dieta insetívora e ritmo alimentar noturno com pico de atividade entre 10:00 até 14:00 horas.

Palavras-chave: ecologia trófica, ritmo alimentar diário, peixes de riacho. 


\section{Introduction}

According to Wootton (1998), an individual fish is a system that converts food into progeny and occupy virtually every possible trophic role, from herbivorous to secondary and tertiary carnivorous. The knowledge of such position in the trophic structure of a given community is hardly important when environmental management is necessarily or even when theoretical inferences are made for natural systems (Winemiller, 1990). Although morphology can provide circumstantial evidence of the diet of a fish, the inferences must be confirmed by more direct evidence of what is eaten. In this context, the description of food items consumed by any fish species in a community is the starting point to the recognition of a natural trophic structure.

Fishes have quite different feeding habits, as well as different morphologies and feed at any time of day or night depending on food availability, possible competitors and physiological characters (Moyle and Cech, 1996). Biological rhythms are characterised by biochemical, physiological and/or behavioural events that occur in regular intervals. Daily rhythm is regulated by day and night light intensity and is dictated by genetically determined endogenous functions (Menna-Barreto and Fortunato, 1988). It is one of the most important behavioural cycles and acts, mainly, on foraging behaviour (Rabelo and Araújo-Lima, 2002; Gerking, 1994).

Foraging behaviour is also constrained by physiological requirements and the circadian rhythm is one of the most important cues for the daily pattern of foraging (Dill, 1983; Rabelo and Araújo-Lima, 2002). Circadian pattern of activity is among the most conservative behaviour in animals and, in the case of fishes, varies according with taxonomic groups; for example, Characiformes are diurnal species but Siluriformes are crepuscular ones (e.g. Sabino and Castro, 1990; Soares-Porto, 1994).

As most catfish rely on their barbels they do not need light to detect food, so, according to Bolliet et al. (2001), in these cases, feeding behaviour is more dependent on food availability than photoperiod. Nonetheless, records found in the literature state that Siluriform species have nocturnal habits as the food intake rhythm is under endogenous control (Eriksson and Van Veen, 1980; Lowe McConnel, 1987; Boujard et al., 1990; Boujard, 1995; Bolliet et al., 2001). This kind of behaviour was registered in several Pimelodella species, a typical Siluriform from Serra do Mar rivers (Sazima, 1986; Trajano, 1989; Soares-Porto, 1994).

Pimelodella lateristriga (Lichtenstein, 1823), also commonly known as "mandi", "mandi-chorão" and "mandizinho" (Bockmann and Guazelli, 2003), is found in the Atlântico Leste microbasins, between Rio Jequitinhonha and Rio Paraíba do Sul (Menezes et al., 2007), and is one of the most abundant species and of large distribution in the Rio Mato Grosso (unpublished data). In the present work we aimed to describe the diet and feeding daily rhythm of P. lateristriga from Rio Mato Grosso, Saquarema - RJ.

\section{Material and Methods}

\subsection{Study area}

The Mato Grosso microbasin $\left(22^{\circ} 55^{\prime} \mathrm{S}\right.$ and $\left.42^{\circ} 35^{\prime} \mathrm{W}\right)$ is a small fluvial system that drains the east watershed of Serra do Mar. Headwaters are located in Serra do Mato Grosso, approximately $800 \mathrm{~m}$ high. Mato Grosso stream is a typical Serra do Mar $3^{\text {rd }}$ order stream and is the main water course in that microbasin (Afonso et al., 2000, Barbieri and Coelho-Neto, 1999; Silva-Filho et al., 1999). It flows down through about $11 \mathrm{~km}$, and discharges its waters into the Saquarema lagoon system, located $90 \mathrm{~km}$ north of Rio de Janeiro metropolis. Water discharge is seasonally determined by rainfall $\left(\sim 1500 \mathrm{~mm} \mathrm{yr}^{-1}\right)$ that is more abundant during summer (November-January) but tropical storms (> $120 \mathrm{~mm}$ in a day) occur throughout the year and may increase water level by several-fold but a return to base-flow conditions occur within the same day. Sunlight daily cycle is seasonally determined but, according to its latitudinal position, photoperiod did not vary for more than 3 horas between - June (winter solstice) and February (summer solstice) (see also Mazzoni and Rezende, 2009). The study site was located in the upper Mato Grosso stream (Figure 1) where the canopy and stream surroundings are well preserved. It was a crystal clear waters site with low turbidity, intact canopy, stony river bed presenting riffles and runs.

\subsection{Sampling and data analysis}

At each sampling month fishes, from a wide range of standard length, were sampled six times, at a 4 hours interval over a 24 hours period (2:00, 6:00, 10:00 AM and 2:00, 6:00, 10:00 PM) on a 150-m-long stream stretch in winter (July/2002 = 11 hours photoperiod) and summer (February $2003=13$ hours photoperiod) of 2003. Sampling was done by electro fishing (Mazzoni et al., 2000) and was always initiated 30 minutes after sunrise (http://www.cptec. inpe.br/). Fifteen $P$. lateristriga specimens were sampled during each sampling time. Specimens were immediately fixed in a $10 \%$ formalin solution for posterior analysis. Thereafter, in the laboratory, fishes were processed and the following data were obtained: (i) standard length $\left(L_{\mathrm{s}}-\mathrm{cm}\right)$, (ii) total weight $\left(W_{\mathrm{t}}-\right.$ gr) e (iii) gut weight $\left(W_{\mathrm{g}}-\right.$ gr). Guts were fixed in 5\% formaldehyde and transferred to $70 \%$ alcohol after a 48-hours period.

Guts content, of 358 specimens, were analysed under a stereoscopic microscope throughout the Volumetric $\left(\mathrm{V}_{\mathrm{o}}\right)$ and Frequency of Occurrence $\left(\mathrm{F}_{\mathrm{O}}\right)$ methods (Hynes, 1950; Hyslop, 1980). The relative importance of each food item/ category was established according to the Feeding Index $\left(\mathrm{IA}_{\mathrm{i}}\right)$. The IA $\mathrm{A}_{\mathrm{i}}$ consisted of the correlation between $F_{\mathrm{O}}$ and $V_{\mathrm{O}}$ data as proposed by Kawakami and Vazzoler (1980) and adapted by Hahn et al. (1997) and was applied according to the following model: $\mathrm{IA}_{\mathrm{i}}=\left(F_{\mathrm{i}}^{*} V_{\mathrm{i}}\right) /\left(\sum F_{\mathrm{i}}^{*} V_{\mathrm{i}}\right) * 100$, where $\mathrm{i}=1,2, \ldots . \mathrm{n}$ food items; $F_{\mathrm{i}}=$ frequency of occurrence and $V_{\mathrm{o}}=$ volume of a given food item. Feeding items were identified according to the corresponding bibliography (Carvalho, 1989, 1992; Carvalho et al., 2001; Melo, 


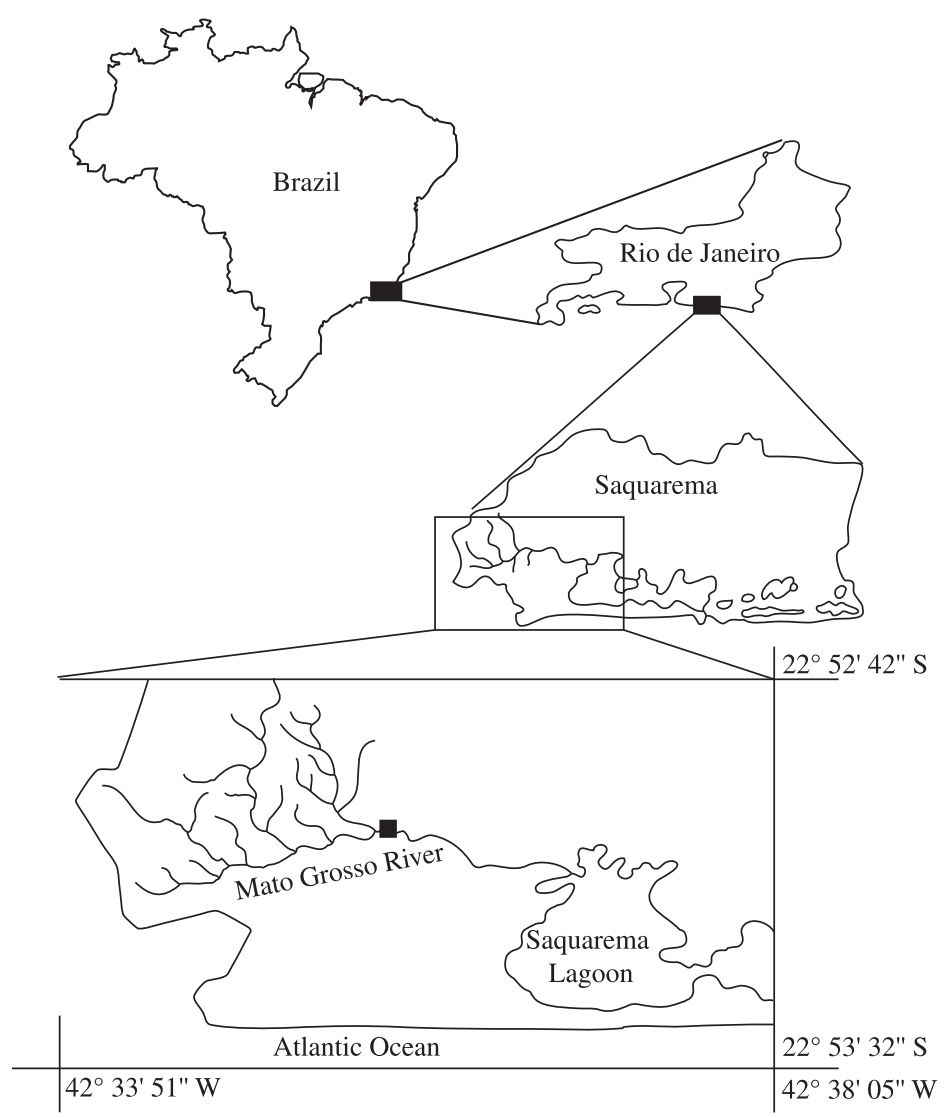

Figure 1. Mato Grosso fluvial system location with the indication of the sampling site (black square) where Pimelodella lateristriga feeding study was developed.

2003; Olifiers et al., 2004; Salles et al., 2004; Borror and Delong, 2005; Pes et al., 2005; Passos et al., 2007). Diet was defined as the relative importance of each food category (animal vs. vegetal) and origin (autochthonous vs. allochthonous).

Gut fullness Index (GFI) (Santos, 1978; Mazzoni and Rezende, 2009) was determined according to the following model: $\mathrm{GFI}=100 \mathrm{~W}_{\mathrm{g}} \mathrm{W}_{\mathrm{t}}^{-1}$, where $\mathrm{W}_{\mathrm{g}}=$ gut weight and $\mathrm{W}_{\mathrm{t}}=$ total weight. Daily activity was estimated as the 24 hours distribution of mean GFI mean values. Normality and homocedasticity premises were verified by the Kolmogorov-Smirnoff and Levine tests, respectively. In order to test the daily variation of food intake, variance analysis (ANOVA) and the pos hoc Tukey test (HSD) were used for the GFI daily variation. Voucher specimens were placed in the ichthyological collection from Museu Nacional do Rio de Janeiro - MNRJ 29,965, MNRJ 29,972, MNRJ 29,995, MNRJ 30,019, MNRJ 30,020 and MNRJ 30,022.

\section{Results}

The individuals of Pimelodella lateristriga that had their guts analysed in the present study varied in size from 3.0 to $11.9 \mathrm{~cm}$ (Figure 2). Diet was composed of 37 items, being aquatic insects the most important ones. According to IAi, Diptera, Trichoptera and Ephemeroptera totalled 90\% of the diet (Table 1). Considering the relative participation of autochthonous $v s$. allochthonous and animal vs. vegetal items, we found that $P$. lateristriga diet was mainly based on animal autochthonous items (Table 1).

We did not find significant differences for the GFI of each sampling time between sampling months $(p>0.05)$ thus, daily feeding activities were based on the grouped data of all sampling months. Feeding activity analyses, based on the average GFI of each sampling period, showed that $P$. lateristriga concentrated feeding activities in the nocturnal period (10:00 PM to 2:00 AM) with marked significant differences $(\mathrm{F}=16.11 ; \mathrm{gl}=5 ; \mathrm{p}<0.05)$ between each sampling time. Between $6 \mathrm{AM}$ and $6 \mathrm{PM}$ the foraging activity was gradually reduced (Figure 3 ).

\section{Discussion}

Longitudinal pattern of food availability is the main characteristic that determines a continuous gradient of biological parameters of streams (Vannote et al., 1980) and should be dictated from the production/input of autochthonous and/or allochthonous matter (Minshall, 1996). The amount and quality of organic matter and light 
availability for photosynthesis are the lotic characteristics strongly dependent from the riparian vegetation (Afonso et al., 2000). Fish communities from opened streams have on autochthonous process, prompted by photosynthesis, its primary food resource (Thorp, 2002; Hein et al., 2003). In opposition, in streams where marginal vegetation is almost abundant, $99 \%$ of the energy that flows through food chain constitutes of vegetal matter and terrestrial insects derived from riparian vegetation (Fisher and Likens, 1973; Gregory et al., 1991; Uieda and Kikuchi, 1995).

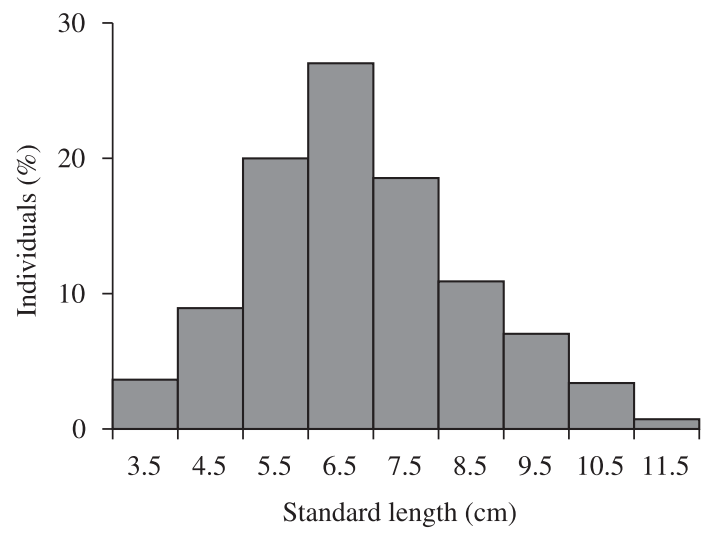

Figure 2. Standard length distribution of Pimelodella lateristriga from Mato Grosso stream, Saquarema, Rio de Janeiro. Numbers in the independent axis concern mid-point of standard length classes $(\mathrm{cm}): 3.5=3.0-3.9 \mathrm{~cm} ; \ldots 11.5=$ $11.0-11.9 \mathrm{~cm}$.

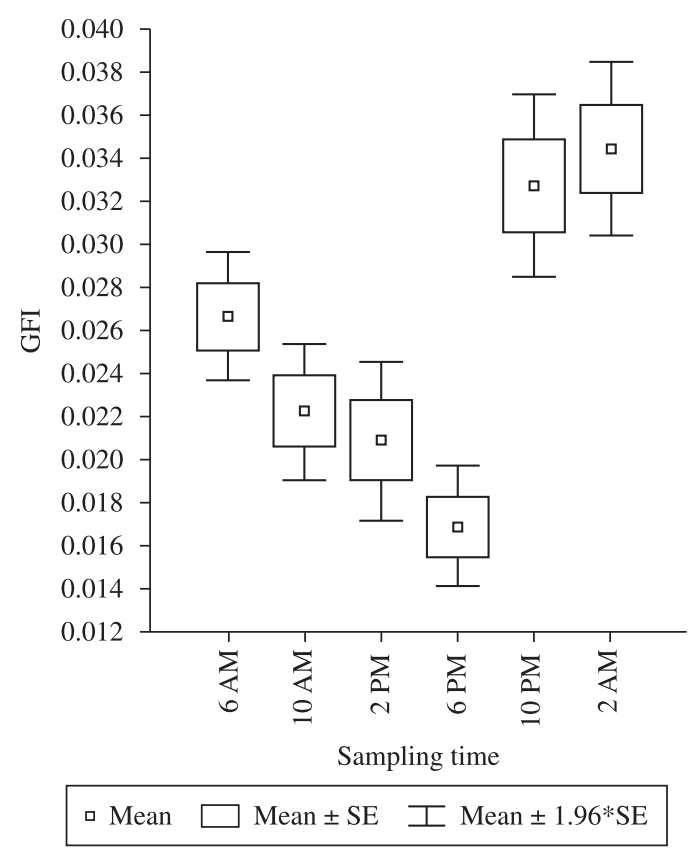

Figure 3. Temporal variation of mean values of the Gut Fullness Index (GFI) of Pimelodella lateristriga from Mato Grosso stream, Saquarema, Rio de Janeiro.
Table 1. Percent composition by volume (Vo) and occurrence (Fo) and Alimentary Index (IAi) of each food item/group registered in the food content of Pimelodella lateristriga from Mato Grosso stream, Saquarema, Rio de Janeiro. Allochthonous items are marked with *.

\begin{tabular}{|c|c|c|c|}
\hline & $V_{o}$ & $\mathbf{F}_{\mathrm{O}}$ & IAi \\
\hline Diptera & & & 72.04 \\
\hline Ceratopogonidae & 0.05 & 2.18 & \\
\hline Chironomidae (larvae 1) & 18.23 & 58.36 & \\
\hline Chironomidae (larvae 2) & 0.02 & 0.73 & \\
\hline Empididae & 0.91 & 18.91 & \\
\hline Muscidae & 0.13 & 0.36 & \\
\hline Psycodidae & 0.00 & 0.36 & \\
\hline Simuliidae (larvae 1) & 19.02 & 48.36 & \\
\hline Simuliidae (larvae 2) & 2.64 & 12.36 & \\
\hline Tipulidae & 0.12 & 0.73 & \\
\hline Diptera - unidentified & 0.01 & 0.36 & \\
\hline Efemeroptera & & & 15.19 \\
\hline Baetidae (larvae 1) & 14.89 & 28.73 & \\
\hline Baetidae (larvae 2) & 0.09 & 1.09 & \\
\hline Ephemeroptera (larvae) & 0.00 & 0.36 & \\
\hline Leptophebiidae & 0.45 & 2.18 & \\
\hline Trichoptera & & & 3.29 \\
\hline Hidroptilidae & 0.30 & 8.00 & \\
\hline Hydropsychidae & 0.74 & 6.18 & \\
\hline Helicopsychidae & 0.57 & 4.36 & \\
\hline Leptoceridae & 3.90 & 21.09 & \\
\hline Philopotamidae & 0.48 & 2.55 & \\
\hline Plecoptera & & & 0.03 \\
\hline Grypopterigidae & 0.29 & 1.09 & \\
\hline Perlidae & 0.33 & 1.45 & \\
\hline Coleoptera & & & 0.34 \\
\hline Elmidae (larvae) & 0.61 & 14.18 & \\
\hline Nocteridae (larvae) & 0.20 & 5.45 & \\
\hline Psephinidae & 0.01 & 0.36 & \\
\hline Odonata & & & 0.02 \\
\hline Libellulidae & 0.27 & 1.45 & \\
\hline Anisoptera & 0.22 & 1.09 & \\
\hline Zigoptera & 0.13 & 0.36 & \\
\hline Lepidopetra & & & 0.55 \\
\hline Pyralidae & 1.69 & 9.09 & \\
\hline Megaloptera & & & 0.05 \\
\hline Corydalidae & 1.87 & 0.73 & \\
\hline Hymenoptera* & 3.89 & 2.55 & 0.35 \\
\hline Hemiptera* & 1.20 & 0.73 & 0.03 \\
\hline Crustaceans & 9.43 & 9.09 & 3.03 \\
\hline Scales & 4.66 & 25.09 & 4.15 \\
\hline Fish parts & 2.61 & 0.73 & 0.07 \\
\hline Seeds* & 5.54 & 1.82 & 0.36 \\
\hline Molusc & 0.05 & 0.73 & $<0.01$ \\
\hline Oligocheata & 4.38 & 3.27 & 0.51 \\
\hline
\end{tabular}


Such environmental differences are normally reflected in fish diet because species show great flexibility in their trophic ecology (Gerking, 1994). In fact, Pimelodella species have been classified in different trophic categories varying between omnivory, feeding upon autochthonous and allochthonous insects, plant parts (Viana et al., 2006) and scales (Costa, 1987) and insectivory, feeding exclusively upon insects (Soares-Porto, 1994; Casatti et al., 2001; Mazzoni and Costa, 2007). These results were obtained from studies developed in $1^{\text {st }}$ and $2^{\text {nd }}$ order streams where environmental parameters are very important for biological processes. In rivers, up to $3^{\text {rd }}$ order, environmental variables are more stable and biological responses, mainly feeding habits, are less dependent on local characteristics.

Pimelodella lateristriga from the Rio Mato Grosso system fed on aquatic (autochthonous) and terrestrial allochthonous insects and presented occasional consumption of vegetal items. Although the species consumed a high number of prey, their diet was largely based on autochthonous resources, mainly Diptera and Ephemeroptera. The consumption of allochthonous vs. autochthonous, bentonic vs. nektonic feeding behaviour were recurrently registered in the literature on Pimelodella species (e.g. Mazzoni and Costa, 2007; Casatti et al., 2001). All of those mentioned differences in the feeding behaviour of Pimelodella species reflected local differences. The study site of the present study was an opened area where autochthonous processes probably superimposed the allochthonous ones. These determined that food availability was based on aquatic insects, adults and larvaes, both dependent on the autochthonous primary production. Thus, following statements from the literature we conclude that food items used by the studied population were largely dependent on autochthonous processes.

In most cases, daily rhythm of feeding activity is related to prey detection. Among visual predators prey consumption decreases under low light conditions, but this does not occur among non-visual predators (Hyatt, 1979). Bolliet et al. (2001) stated that among catfish, as barbels are the main food searching system, food availability is more important than the photoperiod. In the present study we verified low feeding activity during the day, but it is a consistent nocturnal habit. Nonetheless, in most studies on Siluriform species, daily rhythms have shown a nocturnal feeding habit (Lowe McConnell, 1987; Sazima, 1986; Trajano, 1989; Soares-Porto, 1994), however, diurnal habits have also been recorded for some Pimelodidae species (Lolis and Andrian, 1996).

According to Ross (1986) the factors that generate such feeding patterns during the nocturnal period might be related to several factors, such as morphological or philogenetical relationships (Ross, 1986) and this statement explains, up to a certain point, the high incidence of nocturnal feeding habit among Siluriforms. Future research involving morphological variables together with resource availability might be important to explain the result of the foraging habits observed in our study for such species and perhaps to test Bolliet et al. (2001) proposal.
Acknowledgements - We thank the staff of the Laboratório de Ecologia de Peixes from the Universidade do Estado do Rio de Janeiro and the Universidade Federal do Rio de Janeiro for helping in the fieldwork and to FAPERJ/APQ1/E-26/171.555-00 for the financial support.

\section{References}

AFONSO, AAO., HENRY, R. and RODELLA, RCSM., 2000. Allochthonous matter input in two different stretches of a headstream (Itatinga, São Paulo, Brazil). Brazilian Archives of Biology and Technology, vol. 43, no. 3, p. 335-343.

BARBIERI, EB. and COELHO-NETO, R., 1999. Spatial and temporal variation of the east fluminense coast and Atlantic Serra do Mar, state of Rio de Janeiro, Brazil. In KNOPPERS, BA., BIDONE, ED. and ABRÃO, JJ. (Eds.). Environmental Geochemistry of Coastal Lagoon Systems, Rio de Janeiro, Brazil. Niterói: EDUFF, p. 47-56.

BOCKMANN, FA. and GUAZZELLI, GM., 2003. Family Heptapteridae. In REIS, RE., KULLANDER, SO. and FERRARIS Jr, CJ. (Eds.). Check list of the freshwater fishes of South and Central America. Porto Alegre: EDIPUCRS, p. 406-431.

BOLLIET, V., ARANDA, A. and BOUJAD, T., 2001. Demand-feeding rhythm in rainbow trout and European catfish Synchronisation by photoperiod and food availability. Physiology and Behavior, vol. 73 , no. 5, p. 625-633.

BORROR, DJ. and DELONG, DM., 2005. Study of insects. Belmont: Thomson Learning Academic Resource Center, 864 p.

BOUJARD, T., 1995. Diel Rhythms of Feeding Activity in the European Catfish, Silurus glanis. Fhisiology and Behavior, vol. 58, no. 4, p. 641-645.

BOUJARD, T., KEITH, P. and LUQUET, P., 1990. Diel cycle in Hoplosternum littorale (Teleostei): Evidence for synchronization of locomotor, air breathing and feeding activity by circadian alternation of light and dark. Journal of Fish Biology, vol. 36, no. 2, p. 133-140.

CARVALHO, AL., 1989. Description of the larva of Neuraeschna costalis (Burmeister), with notes of its biology, and a key to the genera of Brazilian Aeshnidae Larvae (Anisoptera). Odonatologica, vol. 18 , no. 4 , p. 325-332.

-, 1992. Revalidation of the genus Remartinia Navás, 1911, with the description of a new species and a key to the genera of Neotropical Aeshnidae (Anisoptera). Odonatologica, vol. 21, no. 3, p. 289-298.

CARVALHO, AL., WERNECK-DE-CARVALHO, PC. and CALIL, ER., 2001. Description of the larvae of two species of Dasythemis Karsch, with a key to the genera of Libellulidae occurring in the states of Rio de Janeiro and São Paulo, Brazil (Anisoptera). Odonatologica, vol. 31, no. 1, p.23-33.

CASATTI, L., LANGEANI, F. and CASTRO, RMC., 2001. Peixes de riacho do Parque Estadual Morro do Diabo, bacia do Alto Rio Paraná, SP. Biota Neotropica. Available from: <www. biotaneotropica.org.br/v1n12/pt/fullpaper?bn00201122001>.

COSTA, WJEM., 1987. Feeding Habits of a Fish Community in a Tropical Coastal Stream, Rio Mato Grosso, Brazil. Studies on Neotropical Fauna and Environment, vol. 22, no. 3, p. 145153. 
DILL, LM., 1983. Adaptive Flexibility in the Foraging Behavior of Fishes. Canadian Journal of Fisheries and Aquatic Science, vol. 40, no. 3, p. 398-408.

ERIKSSON, LO. and VEEN, T. van, 1980. Circadian rhythm in the brown bullhead Ictalurus nebulosus (Teleostei): Evidence for an endogenous rhythm in feeding, locomotor and reaction time behaviour. Canadian Journal Zoology, vol. 58, no. 57, p. 1899-1907.

FISHER, SG. and LIKENS, GE., 1973. Energy flow in Bear Brook, New Hampshire: an integrative approach to stream metabolism. Ecological Monographs, vol. 43, no. 4, p. 421-439.

GERKING, SD., 1994. Feeding ecology of fish. San Diego: Academic Press, $416 \mathrm{p}$.

GREGORY, SV., SWANSON, FJ., MCKEE, WA. and CUMMINS, KW., 1991. An Ecosystem perspective of riparian zones. BioScience, vol. 41 , no. 8 , p. 540-551.

HAHN, NS., ALMEIDA, VLL. and LUZ, KDG., 1997. Alimentação e ciclo alimentar diário de Hoplosternum littorale (Hancock) (Siluriformes, Callichthyidae) nas lagoas Guaraná e Patos da Planície do Alto Paraná, Brasi. Revista Brasileira de Zoologia, vol. 14 , no. 1 , p. 57-64.

HEIN, T., BARANYI, C., HERNDL, GJ., WARNEK, W. and SCHIEMER, F., 2003. Allochthonous and autochthnous particulate organic matter in floodplains of the River Danube: the importance of hydrological connectivity. Freshwater Biology, vol. 48, no. 1, p. $220-232$.

HYATT, KD., 1979. Feeding strategy. In HOAR, WS., RANDALL, DJ. and BRETT, JR. (Eds). Fish Physiology. New York: Academic Press, p. 71-119.

HYNES, HBN., 1950. The Food of Fresh-Water Sticklebacks (Gasterosteus aculeatus and Pygosteus pungitius), with a Review of Methods Used in Studies of the Food of Fishes. Journal of Animal Ecology, vol. 19, no. 1, p. 36-58.

HYSLOP, EJ., 1980. Stomach Contents Analysis - a Review of Methods and Their Application. Journal of Fish Biology, vol. 17, no. 4 , p. 411-429.

KAWAKAMI, E. and VAZZOLER, G., 1980. Método gráfico e estimativa de índice alimentar aplicado no estudo da alimentação de peixes. Boletim do Instituto Oceonográfico, vol. 29, no. 2, p. 205-207.

LOLIS, AA. and ANDRIAN, IF., 1996. Alimentação de Pimelodus maculatus Lacépède, 1803 (Siluriformes, Pimelodidae), na planície de inundação do alto rio Paraná, Brasil. Boletim do Instituto de Pesca, vol. 23, p. 187-202.

LOWE-MCCONNELL, RH., 1987. Ecological studies in tropical fish communities. Cambridge: Cambridge University Press, $382 \mathrm{p}$.

MAZZONI, R. and COSTA, LDS., 2007. Feeding Ecology of Stream-Dwelling Fishes from a Coastal Stream in the Southeast of Brazil. Brazilian Archives of Biology and Technology, vol. 50, no. 4 , p. 627-635.

MAZZONI, R. and REZENDE, CF., 2009. Daily Feeding Activity of Bryconamericus microcephalus (Characiformes, Characidae) From Córrego Andorinha, Ilha Grande - RJ. Revista Brasileira de Biologia = Brazilian Journal of Biology, vol. 69, no. 2, p. 631-637.
MAZZONI, R., FRENERICH-VERANI, N. and CARAMASCHI, EP., 2000. Electrofishing as a sampling technique for coastal stream fish populations in the Southeast of Brazil. Revista Brasileira de Biologia = Brazilian Journal of Biology, vol. 60, no. 2, p. 205-216.

MELO, GAS., 2003. Manual de identificação de crustácea decapoda de água doce do Brasil. São Paulo: Loyola, 429 p.

MENEZES, NA., WEITZMAN, SH., OYAKAWA, OS., LIMA, FCT., CASTRO, RMC. and WEITZMAN, MJ., 2007. Peixes de Água Doce da Mata Atlântica: lista preliminar das espécies e comentários sobre conservação de peixes de água doce neotropicais. São Paulo: MZUSP, 408 p.

MENNA-BARRETO, LS. and FORTUNATO, G., 1988. O que é cronobiologia? In CIPOLLA-NETO, J., MARQUES, N. and MENNA-BARRETO, LS. (Eds.). Introdução ao estudo da Cronobiologia. São Paulo: Editora Ícone, p. 15-19.

MINSHALL, GW., 1996. Organic Matter Budgets. In HAUER, FR. and LAMBERT, GA. (Eds.). Methods in Stream Ecology. California: Academic Press, p. 217-229.

MOYLE, PB. and CECH, JJ., 1996. Fishes: an introduction to ichthyology. New Jersey: Prentice Hall, 590 p.

OLIFIERS, MH., DORVILLÉ, LFM. and NESSIMIAN, JL., 2004. A key to Brazilian genera of Plecoptera (Insecta) based on nymphs. Zootaxa, vol. 651, p. 1-15.

PASSOS, MIS., NESSIMIAN, JL. and FERREIRA Jr., N., 2007. Chaves para identificação dos gêneros de Elmidae (Coleóptera) acorrentes no estado do Rio de Janeiro, Brasil. Revista Brasileira de Entomologia, vol. 51, no. 1, p. 42-53

PES, AMO., HAMADA, N. and NESSIMIAN, JL., 2005. Chaves de identificação de larvas para famílias e gêneros de Trichoptera (Insecta) da Amazônia Central, Brasil. Revista Brasileira de Entomologia, vol. 49, no. 2, p. 181-204.

RABELO, H. and ARAÚJO-LIMA, CARM., 2002. A dieta e o consumo diário de alimento de Cichla monoculus na Amazônia Central. Acta Amazônica, vol. 32, no. 4, p. 707-724.

ROSS, ST., 1986. Resource Partitioning in Fish Assemblages - a Review of Field Studies. Copeia, vol. 2, p. 352-388.

SABINO, J. and CASTRO, CMR., 1990. Alimentação, período de atividade e distribuição espacial dos peixes de um riacho da floresta Atlântica (Sudeste do Brasil). Revista Brasileira de Biologia $=$ Brazilian Journal of Biology, vol. 50, no. 1, p. 23-26.

SALLES, FF., DA-SILVA, ER., SERRÃO, JR. and FRANCISCHETTI, CN., 2004. Baetidae (Ephemeroptera) na região Sudeste do Brasil: Novos registros e chave para os gêneros no estágio ninfal. Neotropical Entomology, vol. 33, no. 5, p. 725-735.

SANTOS, EP., 1978. Dinâmica de população aplicada à pesca e à piscicultura. São Paulo: Hucitec, 129 p.

SAZIMA, I., 1986. Similarities in feeding behaviour between some marine and freshwater fishes in two tropical communities. Journal of Fish Biology, vol. 29, no. 1, p. 53-65.

SILVA-FILHO, EV., PEDLOWSKI, MA., PAIVA, RP., WASSERMAN, JC. and LACERDA, LD., 1999. Atmospheric inputs to ecosystems of the east coast of Rio de Janeiro state. In KNOPPERS, BA., BIDONE, ED. and ABRÃO, JJ. (Orgs.). Environmental geochemistry of coastal lagoon systems of Rio de Janeiro, Brazil. Niterói: Universidade Federal Fluminense, p. 71-87. 
SOARES-PORTO, LM., 1994. Dieta e ciclo diurno de atividade alimentar de Pimelodella lateristriga (Muller e Troschel, 1849) (Siluroidei, Pimelodidae) no rio Ubatiba, Maricá, Rio de Janeiro. Revista Brasileira de Biologia = Brazilian Journal of Biology, vol. 54, no. 3, p. 451-458.

THORP, JH., 2002. Dominance of autochthonous autotrophic carbon in food webs of heterotrophic rivers. Oikos, vol. 93, no. 5 , p. $543-550$.

TRAJANO, E., 1989. Estudo do comportamento espontâneo e alimentar da dieta do bagre cavernícola, Pimelodella kronei, e seu provável ancestral epígeo, Pimelodella transitória (Siluriformes, Pimelodidae). Revista Brasileira de Biologia = Brazilian Journal of Biology, vol. 49, no. 3, p. 757-769.

UIEDA, VS. and KIKUCHI, RM., 1995. Entrada de material alóctone (detritos vegetais e invertebrados terrestres) num pequeno curso de água corrente na cuesta de Botucatu, São Paulo. Acta Limnologica Brasiliensis, vol. 7, no. 1, p. 105-114.

VANNOTE, RL., MINSHALL, GW., CUMMINS, KW., SEDELL, JR. and CUSHING, CE., 1980. The river continuum concept. Canadian Journal of Fisheries and Aquatic Sciences, vol. 37, no. 1 , p. 130-137.

VIANA, LF., SANTOS, SL. and LIMA-JÚNIOR, SE., 2006. Variação sazonal na alimentação de Pimelodella cf. gracilis (Osteichthyes, Siluriformes, Pimelodidae) no rio Amambaí, Estado de Mato Grosso do Sul. Acta Scientiarum Biological Sciences, vol. 28, no. 2, p. 123-128.

WINEMILLER, KO., 1990. Spatial and temporal variation in tropical fish trophic networks. Ecological Monographs, vol. 60, no. 3 , p. 331-367.

WOOTTON, RJ., 1998. Ecology of teleost fishes. London: Kluwer Academic Publishers, 386 p. 
